\title{
Applicability of Atomic Emission and Atomic Absorption Spectrometry for Variability Assessment of Trace and Macro-Elements Content in Moss Species from $\mathrm{Pb}-\mathrm{Zn}$ Mine Environment
}

\author{
Svetlana Angelovska ${ }^{1}$, Trajce Stafilov ${ }^{2 *}$, Biljana Balabanova ${ }^{3}$, Robert Sajn ${ }^{4}$ and Katerina Baceva ${ }^{2}$ \\ ${ }^{1} R Z$ Tehnicka Kontrola, Makedonska Brigade 18, 1000 Skopje, Macedonia \\ 2 Institute of Chemistry, Faculty of Natural Sciences and Mathematics, Ss. Cyril and Methodius University, POB 162, 1000 Skopje, Macedonia \\ ${ }^{3}$ Faculty of Agriculture, Goce Delcev University, POB 201, 2000 Stip, Macedonia \\ ${ }^{4}$ Geological Survey of Slovenia, Dimiceva ulica 14, 1000 Ljubljana, Slovenia
}

\begin{abstract}
The aim of this study was to assess the applicability of the Inductively Coupled Plasma-Atomic Emission Spectrometry (ICP-AES) Electro Thermal Atomic Absorption Spectrometry (ETAAS), and Cold Vapour Atomic Absorption Spectrometry (CVAAS) for the analysis of total content for 23 elements. Deposition and distribution of metals in the air was determined by biomonitoring a widely prevalent moss species from a lead and zinc polluted area of the "Toranica" mine, Republic of Macedonia. Moss species Hypnum cupressiforme, Homalothecium lutescens, Campthotecium lutescens and Brachythecium glareosum were used as very specific and suitable sampling biomonitor. Moss samples were digested by the application of a closed wet digestion using a microwave digestion system. The applied instrumental techniques were useful in order to determine a wider range of content for the analyzed elements; macro contents of $\mathrm{Ca}, \mathrm{Mg}, \mathrm{K}$ and $\mathrm{P}$ to trace contents of $\mathrm{As}, \mathrm{Cd}, \mathrm{Co}, \mathrm{Ga}$, and $\mathrm{Hg}$. From data processing the values for $\mathrm{Pb}$ and $\mathrm{Zn}$ were used as anthropogenic markers. Higher contents of $\mathrm{As}, \mathrm{Cd}$ and $\mathrm{Cu}$ in moss samples from this region were also determined, confirming the impact of mining activities on anthropogenic air pollution in this area. Multivariate factoring identifies four chemical associations: F1 (As-Cd-Ca-Cu-Fe-Mn-Pb-Zn), F2 (Co-Cr-Li-V), F3 (Hg-P) and F4 $(\mathrm{K})$.
\end{abstract}

Keywords: Air pollution; Moss biomonitoring; Heavy metals; ICPAES; ETAAS; CVAAS

\section{Introduction}

Environmental pollution has been known as one of the most important problems in modern societies. Heavy metals are a major source of environmental pollution, and determining their environmental concentrations is an important part of understanding biogeochemical processes and gauging ecosystem's health [1]. Human activities, such as mining and tailings discharge processes are rapidly increasing environmental pollution $[2,3]$. Emissions into the air constitute the greatest source of the toxic metals pollution. Even the metals emitted naturally in wind-blowing dust are often of anthropogenic sources. Therefore, it is necessary to maintain a close watch on heavy metal depositions, even when local or regional areas are monitored. Specific danger arises from waste processing ore and flotation tailings in mine plants surroundings. Metals content quantifications present an ecological for the determination not only of the presence of metals but also their distribution and extent of toxicology for the environment and human health [4].

The use of mosses as biomonitors in smaller scale is a convenient way of determining levels of atmospheric deposition [5-8]. This is possible because mosses absorb/adsorb nutrients, and also contaminants, directly from the atmosphere. Compared to higher plants, mosses have several advantages which make them more suitable for this kind of study [9]. Mosses lack a root system and a well-developed cuticle, thus the substrate has little influence on the levels of contaminants in their tissues and they readily take up atmospheric contaminants. Moreover, the cationic exchange capacity in mosses is high and they possess a high surface area to volume ratio, factors which both favor the accumulation of large amounts of pollutants [10]. Bryophytes are especially suitable organisms for purposes of monitoring investigations, because procedures of sampling and chemical analyses are relatively simple and of low-cost. Bryophytes include evergreen and perennial plants, making it possible to collect them year round. Most of their species are widespread, and, thus, heavy metal concentrations of distant areas can also be compared [11].

Determination of enriched contents for certain toxic elements (As, $\mathrm{Cd}, \mathrm{Cr}, \mathrm{Cu}, \mathrm{Hg}, \mathrm{Ni}$ and $\mathrm{Pb}$ ) occurring in moss species as an accumulator medium, present a challenge for analytical determination. These elements occur from trace contents to micro and macro contents in polluted areas. Thus it is necessary to find the most appropriate techniques for their quantification. Widely used instrumental techniques for multielement analyses like Inductively Coupled Plasma-Atomic Emission Spectrometry (ICP-AES) or Inductively Coupled Plasma-Mass Spectrometry (ICP-MS) are used by numerous investigations [12-14]. However, the elemental analyses like Electro Thermal Atomic Absorption Spectrometry (ETAAS) for ultratrace elements (As, Co) and Cold Vapour Atomic Absorption Spectrometry (CVAAS) for mercury determination are still the most efficient instrumental analytical techniques [5].

The present study is the first attempt to characterize the atmospheric deposition of 23 elements in "Toranica" lead-zinc mine vicinity by means of mosses. Therefore, the aims of this study were: 1) quantification of metals in the air in terms of determination of elements contents in mosses as well as by calculated deposition rates; 2) patterns

*Corresponding author: Trajce Stafilov, Institute of Chemistry, Faculty of Natural Sciences and Mathematics, Ss. Cyril and Methodius University, POB 162, 1000 Skopje, Macedonia, Tel: +3892-324-9906; Fax: +3892-322-6865 E-mail: trajcest@pmf.ukim.mk

Received December 26, 2013; Accepted March 11, 2014; Published March 14 2014

Citation: Angelovska S, Stafilov T, Balabanova B, Sajn R, Baceva K (2014) Applicability of Atomic Emission and Atomic Absorption Spectrometry for Variability Assessment of Trace and Macro-Elements Content in Moss Species from Pb-Zn Mine Environment. Mod Chem appl 2: 123. doi:10.4172/2329-6798.1000123

Copyright: (c) 2014 Angelovska S, et al. This is an open-access article distributed under the terms of the Creative Commons Attribution License, which permits unrestricted use, distribution, and reproduction in any medium, provided the original author and source are credited. 
Citation: Angelovska S, Stafilov T, Balabanova B, Sajn R, Baceva K (2014) Applicability of Atomic Emission and Atomic Absorption Spectrometry for Variability Assessment of Trace and Macro-Elements Content in Moss Species from Pb-Zn Mine Environment. Mod Chem appl 2: 123. doi:10.4172/2329-6798.1000123

Page 2 of 6
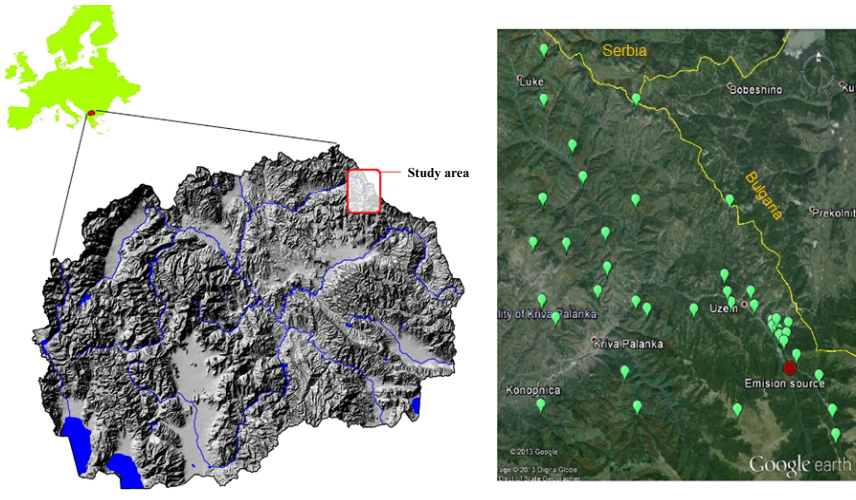

Figure 1: Location of the investigating area in the $\mathrm{Pb}-\mathrm{Zn}$ "Toranica" mine within territory of the Republic of Macedonia (left); moss sampling network (random sampling and $5 \times 5 \mathrm{~km}$ organize sampling) of moss species.

\begin{tabular}{|c|c|c|c|c|c|}
\hline Element & $\begin{array}{c}\text { Wavelength, } \\
\mathbf{n m}\end{array}$ & Element & $\begin{array}{c}\text { Wavelength, } \\
\mathbf{n m}\end{array}$ & Element & $\begin{array}{c}\text { Wavelength, } \\
\mathbf{n m}\end{array}$ \\
\hline $\mathrm{Al}$ & 396.152 & $\mathrm{~K}$ & 766.491 & $\mathrm{Ni}$ & 231.604 \\
\hline $\mathrm{B}$ & 249.772 & $\mathrm{Ga}$ & 294.363 & $\mathrm{P}$ & 213.618 \\
\hline $\mathrm{Ba}$ & 455.403 & $\mathrm{Li}$ & 670.783 & $\mathrm{~Pb}$ & 220.353 \\
\hline $\mathrm{Ca}$ & 370.602 & $\mathrm{Mg}$ & 279.553 & $\mathrm{Sr}$ & 407.771 \\
\hline $\mathrm{Cr}$ & 267.716 & $\mathrm{Mn}$ & 257.610 & $\mathrm{~V}$ & 292.401 \\
\hline $\mathrm{Cu}$ & 324.754 & $\mathrm{Na}$ & 589.592 & $\mathrm{Zn}$ & 213.857 \\
\hline $\mathrm{Fe}$ & 238.204 & & & & \\
\hline
\end{tabular}

Table 1: Wavelengths monitored for measuring light emission of elements by ICPAES.

establishment of elements distribution and identification of affected area of contamination; 3 ) comparative analyses for determining possible variations in four bryophyte species: Homalothecium lutescens, Hypnum cupressiforme, Brachythecium glareosum and Campthotecium lutescens 4) development of optimal methodological approach for instrumental analysis using ICP-AES, ETAAS, and CVAAS for the determination of 23 elements contents: $\mathrm{Al}, \mathrm{As}, \mathrm{B}, \mathrm{Ba}, \mathrm{Ca}, \mathrm{Cd}, \mathrm{Cr}, \mathrm{Co}, \mathrm{Cu}, \mathrm{Ga}, \mathrm{Fe}, \mathrm{Hg}, \mathrm{K}$, Li, Mg, Mn, Na, Ni, P, Pb, Sr, V, Zn.

\section{Material and Methods}

\section{Investigating area description and sample collection}

A total of $250 \mathrm{~km}^{2}$ area was monitored, limited with coordinates $\mathrm{N}: 42^{\circ} 10^{\prime}-42^{\circ} 20^{\prime}$ and E: $22^{\circ} 17^{\prime}-22^{\circ} 28^{\prime}$, located in the north-eastern part of the Republic of Macedonia (Figure 1). Lead and zinc "Toranica" mine environ was monitored as a potentially polluted area with anthropogenic introduced higher contents of certain heavy metals. The "Toranica" mine is located on the slopes of Osogovo Mountain near the Macedonian-Bulgarian border, $18 \mathrm{~km}$ away, and $20 \mathrm{~km}$ away from the town of Kriva Palanka. Mine "Toranica" is designed as a modern uderground mine with a production capacity of 700,000 tons of ore per year. Ore from the deposit "Toranica" appears in three textured types: pure ore with representation of $51 \%$, massive ore with $29 \%$ and impregnated ore with $20 \%$. The ore consists mainly of galena, sphalerite, chalcopyrite and pyrite [15]. The ore reserves were estimated to be 12.6 million tones, with $4.47 \%$ of $\mathrm{Pb}, 2.93 \%$ of $\mathrm{Zn}$ and $20 \mu \mathrm{g} \mathrm{g}{ }^{-1}$ of $\mathrm{Ag}$ [16]. The flotation plant for the production of $\mathrm{Pb}$ and $\mathrm{Zn}$ concentrates is situated close to the mine. Toranica concentrator flowsheet gives the following technological results: $\mathrm{Pb}+\mathrm{Zn}$ collective concentrate with average $15 \%$ of $\mathrm{Pb}$ and $35 \%$ of $\mathrm{Zn}$ and $\mathrm{Pb}$ selective concentrate with an average of $73 \%$ of $\mathrm{Pb}$ and $4,3-5 \%$ of $\mathrm{Zn}$ [15].

The study area region is characterized by moderate continental climate. The altitude varies between 600 and $1500 \mathrm{~m}$. Most frequent winds in the region are those from the west with frequency of $199 \%$ and $2.7 \mathrm{~m} \mathrm{~s}^{-1}$ speed, and winds from the east with frequency of $124 \%$ and $2.0 \mathrm{~m} \mathrm{~s}^{-1}$ speed [17]. Climatic condition in the region allowing airdistribution of fine dust particles generated as a result of mine activities and exposure flotation tailings at open.

The study area is characterized with the presence of four moss species: Homalothecium lutescens, Hypnum cupressiforme, Brachythecium glareosum, and Campthotecium lutescens. The dominant moss species were Homalothecium lutescens (52\% of 39 total collected moss species) and Hypnum cupressiforme (36\% of total collected moss species), while the Brachythecium glareosum and Campthotecium lutescens were collected from two locations. Depending on the conditions and the accessibility of the locations the species that is available and typical for the region was collected according to previously adapted protocol given by Harmens et al. [18]. Random samples (in the very close vicinity of the pollution source) and samples according to sampling network $(5 \times$ $5 \mathrm{~km}$ ) were collected as presented in figure 1 .

\section{Sample preparation}

For digestion of moss samples, the microwave digestion system (CEM, model Mars) was applied. Precisely measured mass $(0.5000 \mathrm{~g})$ of moss samples where mixed with $5 \mathrm{~mL}$ concentrated $\mathrm{HNO}_{3}$ (trace pure), and $2 \mathrm{~mL} \mathrm{H}_{2} \mathrm{O}_{2}(30 \%, \mathrm{~m} / \mathrm{V})$. The Teflon vessels were carefully closed and the microwave digestion method was applied. The digestion method was performed in two steps for total dissolving of moss tissue as previously established by Balabanova et al. [5]. After the digestion method was finished, digests were quantitatively transferred into $25 \mathrm{~mL}$ volumetric flaks. Thus, prepared digests from moss tissue were analysed for the total elements contents.

\section{Quantifications of elements contents using ICP-AES, ETAAS and CVAAS}

The analyses of 23 element contents in digested samples were performed by applying: a) atomic emission spectroscopy with inductively coupled plasma, ICP-AES (Varian, 715ES), with an application of an ultrasonic nebulizer CETAC (ICP/U-5000AT+) for better sensitivity of plants digests, for $\mathrm{Al}, \mathrm{B}, \mathrm{Ba} \mathrm{Ca}, \mathrm{Cr}, \mathrm{Cu}, \mathrm{Ga}, \mathrm{Fe}, \mathrm{K}, \mathrm{Li}$, $\mathrm{Mg}, \mathrm{Mn}, \mathrm{Na}, \mathrm{Ni}, \mathrm{P}, \mathrm{Pb}, \mathrm{Sr}, \mathrm{V}, \mathrm{Zn}$; b) electrothermal atomic absorption spectroscopy, ETAAS (Varian, SpectrAA 640Z) applied for the analyses of As, Co, and Cd; c) cold vapour atomic absorption spectroscopy, CVAAS (Varian, SpectrAA) applied for the analysis of $\mathrm{Hg}$. The optimization of the instrumental parameters for ICP-AES are given as follows: optimal parameters for RF Generator are given by operating frequency of $40.68 \mathrm{MHz}$, power output of $1500 \mathrm{~W}$ to obtain power output stability better than $0.1 \%$. The spectrometer optimization was considered with manufacture recommendations. The variables settings of the program were set as: plasma Ar flow rate $15 \mathrm{~L} \mathrm{~min}^{-1}$, auxiliary $\mathrm{Ar}$ flow rate $1.5 \mathrm{~L} \mathrm{~min}^{-1}$, nebulizer Ar flow rate $0.75 \mathrm{~L} \mathrm{~min}^{-1}$, pump speed of $25 \mathrm{rpm}$, stabilization time $30 \mathrm{~s}$, rinse time $30 \mathrm{~s}$, sample delay $30 \mathrm{~s}$, number of replicates for the quantification measurements-3 (Table 1).

Optimal instrumental parameters for ETAAS determination are given in table 2. The CVAAS is the most successful and widely used technique for the determination of mercury due to its simplicity and good reproducibility. Mercury can stay in its atomic state at room temperature. The vapor pressure of mercury at $20^{\circ} \mathrm{C}$ is $0.16 \mathrm{~Pa}$ that corresponds to $14 \mathrm{mg} \mathrm{m}^{-3}$ mercury concentration in air. The solution of $\mathrm{SnCl}_{2}(1 \%, \mathrm{~m} / \mathrm{V})$ was used for the reduction of $\mathrm{Hg}$ into elemental form in $0.1 \mathrm{~mol} \mathrm{~L}^{-1} \mathrm{HCl}$ reaction medium [19]. Mercury vapor after volatilization is released out of the solution and carried by an inert gas to 
Citation: Angelovska S, Stafilov T, Balabanova B, Sajn R, Baceva K (2014) Applicability of Atomic Emission and Atomic Absorption Spectrometry for Variability Assessment of Trace and Macro-Elements Content in Moss Species from Pb-Zn Mine Environment. Mod Chem appl 2: 123. doi:10.4172/2329-6798.1000123

Page 3 of 6

\begin{tabular}{|c|c|c|c|}
\hline Parameter & As & Cd & Co \\
\hline Wavelength, $\mathrm{nm}$ & 193.7 & 288.8 & 242.5 \\
\hline Spectral width slit, $n m$ & 0.2 & 0.5 & 0.2 \\
\hline Calibration mode & \multicolumn{3}{|c|}{ Peak height } \\
\hline Lamp current, mA & 10.0 & 4.0 & 7.0 \\
\hline \multicolumn{4}{|c|}{ Step 1 (drying) } \\
\hline Temperature, ${ }^{\circ} \mathrm{C}$ & 120 & 120 & 120 \\
\hline Ramp time, $s$ & 55 & 55 & 55 \\
\hline Hold time, s & - & - & - \\
\hline \multicolumn{4}{|c|}{ Step 2 (pyrolysis) } \\
\hline Temperature, ${ }^{\circ} \mathrm{C}$ & 1400 & 250 & 400 \\
\hline Ramp time, $\mathrm{s}$ & 10 & 5 & 5 \\
\hline Hold time, $s$ & 35 & 15 & 22 \\
\hline \multicolumn{4}{|c|}{ Step 3 (atomizing) } \\
\hline Temperature, ${ }^{\circ} \mathrm{C}$ & 2600 & 1800 & 2300 \\
\hline Ramp time, $\mathrm{s}$ & 1 & 1 & 1 \\
\hline Hold time, $s$ & 2 & 2 & 2 \\
\hline \multicolumn{4}{|c|}{ Step 4 (cleaning) } \\
\hline Temperature, ${ }^{\circ} \mathrm{C}$ & 2600 & 1800 & 2650 \\
\hline Time, $\mathrm{s}$ & 2 & 2 & 5 \\
\hline
\end{tabular}

Table 2: Operating condition and wavelengths for As, Co and Cd for ETAAS.

\begin{tabular}{|c|c|}
\hline Elements & \multicolumn{2}{|c|}{ Detection Limit (in $\mathbf{~ m g ~ k}^{-1}$ ) } \\
\hline & \multicolumn{2}{|c|}{ ETAAS } \\
\hline $\mathrm{Cd}, \mathrm{Co}$ & 0.1 \\
\hline $\mathrm{As}$ & 0.2 \\
\hline $\mathrm{Mn}$ & \\
\hline $\mathrm{Zn}$ & 0.0015 \\
\hline $\mathrm{Fe}$ & 0.003 \\
\hline $\mathrm{Al}, \mathrm{Cu}$ & 0.006 \\
\hline $\mathrm{Ga}, \mathrm{Ba}, \mathrm{Ca}, \mathrm{Mg}, \mathrm{Sr}$ & 0.0125 \\
\hline $\mathrm{B}, \mathrm{Cr}, \mathrm{Li}, \mathrm{V}$ & 0.025 \\
\hline $\mathrm{Ni}$ & 0.05 \\
\hline $\mathrm{P}, \mathrm{Pb}$ & 0.25 \\
\hline $\mathrm{Na}$ & 0.5 \\
\hline $\mathrm{K}$ & 2.5 \\
\hline & \\
\hline $\mathrm{Hg}$ & 5 \\
\hline
\end{tabular}

Table 3: Lower detection limits of determinations for ETAAS, CVAAS and ICP-AES for analyzed elements.

the absorption cell. The mercury absorption line is has the wavelength of $253.7 \mathrm{~nm}$. The magnitude of the signal shows the amount of mercury present in the samples.

The QC/QA of the applied techniques was performed by standard addition method, and it was found that the recovery for the investigated elements ranges for ICP-AES 98.5-101.2\%, for ETAAS and CVAAS 96.9-103.2\%. The same methods were applied for the determination of the elements in moss certificated reference materials M2 and M3 [20]. The sensitivity in regard to the lower limit of detection was done as given in table 3 .

\section{Data processing for elements contents}

The obtained values for the contents of the investigated elements were statistically processed using basic descriptive statistics. The application of bivariate statistics was used for data check of elements contents correlations. For that issue the linear coefficient of correlation was used. Two-dimensional scatterplots were used to visualize relations between two data sets. Individual data points were represented by point markers in two-dimensional space, where axes represent the variables.
Multivariate statistical method (cluster and R-mode factor analyses) was used to reveal the associations of the chemical elements. The factor analysis was performed on variables standardized to zero mean and unit standard deviation $[21,22]$. As a measure of similarity between variables, the product-moment correlation coefficient (r) was applied. There are various rotational strategies that have been proposed [22]. The goal of all of these strategies is to obtain a clear pattern of factor scores, that is, factors that are somehow clearly marked by high loadings for some variables and low loadings for others. The elements with low communalities were excluded because of their lack of significant associations. In this study, the varimax method was used for orthogonal rotation. As before, we want to find a rotation that maximizes the variance on the new axes; put another way, we want to obtain a pattern of loadings on each factor that is as diverse as possible, lending itself to easier interpretation. Statistical softer Statistica 8.0. was used for data processing the obtained values for elements contents.

\section{Results and Discussion}

The descriptive statistics of analyzed elements is presented in table 4. On the basis of the normality tests and compared with histograms of distribution for the content of all analyzed elements in moss samples, the normality was assumed for the values of $\mathrm{Al}, \mathrm{Ca}, \mathrm{Cr}, \mathrm{Hg}, \mathrm{K}, \mathrm{Na}$, and $\mathrm{Sr}$. High contents of $\mathrm{Pb}$ and $\mathrm{Zn}$ were assumed (average values 60 and $75 \mathrm{mg} \mathrm{kg}^{-1}$, respectively) in the area very close to the pollution source. However, distribution of dust with high $\mathrm{Pb}-\mathrm{Zn}$ contents was expected in the investigated area. The maximum values $\left(420 \mathrm{mg} \mathrm{kg}^{-1}\right.$ for $\mathrm{Pb}$ and $180 \mathrm{mg} \mathrm{kg}^{-1}$ for $\mathrm{Zn}$ ) for the contents in moss occur in very close vicinity

\begin{tabular}{|c|c|c|c|c|c|c|c|c|c|c|c|}
\hline Element & $x_{a}$ & $x_{g}$ & Md & Min & Max & $\mathbf{P}_{10}$ & $P_{90}$ & $\mathbf{S}$ & CV & A & $\mathbf{S}$ \\
\hline $\mathrm{Al}$ & 1038 & 907 & 989 & 203 & 2818 & 343 & 1892 & 535 & 51.5 & 1.30 & 2.76 \\
\hline As & 0.80 & 0.30 & 0.25 & 0.03 & 10.5 & 0.09 & 1.62 & 1.86 & 233 & 4.31 & 20.4 \\
\hline B & 5.17 & 3.71 & 3.62 & 1.13 & 26.7 & 1.52 & 9.85 & 5.25 & 102 & 2.98 & 11.2 \\
\hline $\mathrm{Ba}$ & 33.9 & 28.0 & 26.3 & 5.76 & 98.2 & 8.54 & 70.1 & 21.5 & 63.4 & 1.30 & 1.28 \\
\hline $\mathrm{Ca}$ & 5929 & 5659 & 5915 & 2360 & 10587 & 4136 & 8098 & 1795 & 30.3 & 0.57 & 0.79 \\
\hline $\mathrm{Cd}$ & 0.31 & 0.19 & 0.15 & 0.06 & 1.62 & 0.06 & 0.96 & 0.37 & 120 & 2.17 & 4.19 \\
\hline Co & 0.30 & 0.17 & 0.15 & 0.02 & 1.36 & 0.04 & 0.80 & 0.35 & 117 & 1.98 & 3.34 \\
\hline $\mathrm{Cr}$ & 1.73 & 1.62 & 1.62 & 0.48 & 4.00 & 0.97 & 2.64 & 0.66 & 37.8 & 1.10 & 2.74 \\
\hline $\mathrm{Cu}$ & 6.20 & 5.73 & 5.56 & 2.23 & 16.3 & 3.62 & 10.1 & 2.69 & 43.3 & 1.60 & 3.88 \\
\hline $\mathrm{Fe}$ & 1408 & 1046 & 1158 & 164 & 7113 & 331 & 2790 & 1270 & 90.2 & 2.78 & 10.3 \\
\hline $\mathrm{Ga}$ & 1.61 & 1.37 & 1.51 & 0.21 & 2.88 & 0.99 & 2.69 & 0.80 & 49.4 & 0.18 & -0.50 \\
\hline $\mathrm{Hg}$ & 0.02 & 0.02 & 0.02 & 0.01 & 0.04 & 0.01 & 0.03 & 0.01 & 46.0 & -0.03 & 1.13 \\
\hline K & 4065 & 3927 & 3896 & 2184 & 8300 & 2640 & 5412 & 1131 & 27.8 & 1.35 & 3.92 \\
\hline Li & 0.69 & 0.57 & 0.56 & 0.13 & 2.52 & 0.23 & 1.36 & 0.50 & 72.8 & 2.46 & 6.64 \\
\hline $\mathrm{Mg}$ & 1692 & 1607 & 1649 & 846 & 2489 & 975 & 2376 & 525 & 31.0 & -0.05 & -1.40 \\
\hline $\mathrm{Mn}$ & 209 & 159 & 156 & 30.4 & 815 & 48.1 & 430 & 160 & 76.1 & 1.68 & 4.13 \\
\hline $\mathrm{Na}$ & 65.3 & 60.7 & 59.5 & 22.3 & 133 & 32.3 & 106 & 25.4 & 38.9 & 0.79 & 0.51 \\
\hline $\mathrm{Ni}$ & 2.88 & 2.51 & 2.84 & 0.45 & 9.43 & 1.05 & 4.75 & 1.56 & 54.0 & 1.93 & 7.27 \\
\hline$P$ & 1419 & 1382 & 1350 & 1028 & 2172 & 1041 & 1713 & 347 & 24.5 & 0.79 & 0.32 \\
\hline $\mathrm{Pb}$ & 31.6 & 6.25 & 3.21 & 0.43 & 421 & 1.44 & 64.1 & 80.8 & 255 & 3.81 & 15.4 \\
\hline $\mathrm{Sr}$ & 18.6 & 17.1 & 18.1 & 7.5 & 49.0 & 8.6 & 26.6 & 7.92 & 42.7 & 1.66 & 4.96 \\
\hline V & 2.18 & 1.68 & 2.01 & 0.21 & 7.06 & 0.69 & 4.82 & 1.53 & 70.2 & 1.33 & 1.83 \\
\hline $\mathrm{Zn}$ & 34.7 & 25.6 & 19.4 & 6.7 & 179 & 12.7 & 81.3 & 34.5 & 99.4 & 2.60 & 7.75 \\
\hline
\end{tabular}

Table 4: Descriptive statistics for the analyzed elements in collected moss species $(\mathrm{n}=39)$

Values given in $\mathrm{mg} \mathrm{kg}^{-1} ; X_{\mathrm{a}}$ : mean; $X_{g}$ : Geometric Mean; Md: Median; Min: Minimum; Max: Maximum; $\mathrm{P}_{10}: 10$ percentile; $\mathrm{P}_{90}: 90$ percentile; $\mathrm{S}$ : Standard Deviation; $\mathrm{CV}$ : Coefficient of Variation; A: Skewness; E: Kurtosis; S: Skewness; bolded values indicated higher anthropogenic introducing in the air of these elements 
Citation: Angelovska S, Stafilov T, Balabanova B, Sajn R, Baceva K (2014) Applicability of Atomic Emission and Atomic Absorption Spectrometry for Variability Assessment of Trace and Macro-Elements Content in Moss Species from Pb-Zn Mine Environment. Mod Chem appl 2: 123. doi:10.4172/2329-6798.1000123

Page 4 of 6

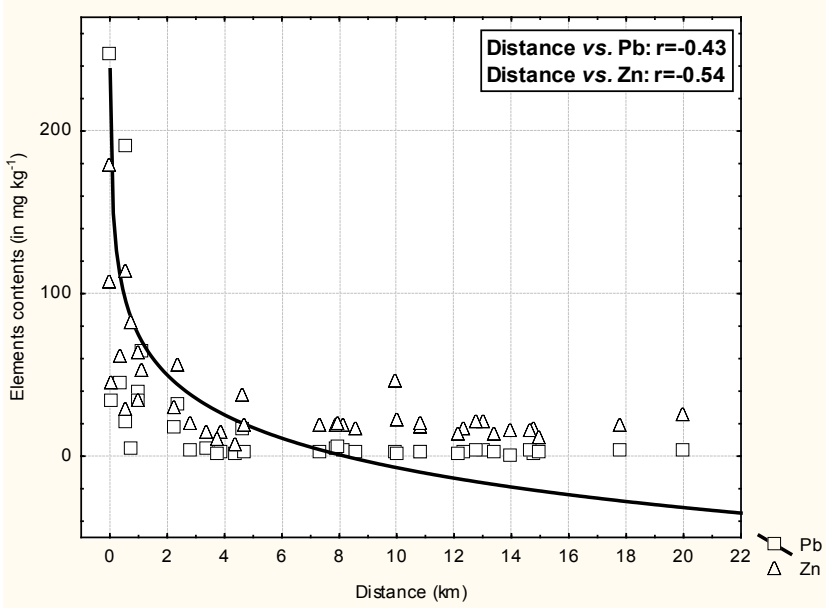

Figure 2: Exponential interdependence relation with the distance from the pollution source for $\mathrm{Pb}$ and $\mathrm{Zn}(\mathrm{n}=39)$; contents for $\mathrm{Pb}$ and $\mathrm{Zn}$ are functionally interdependent with distancing from the pollution source.

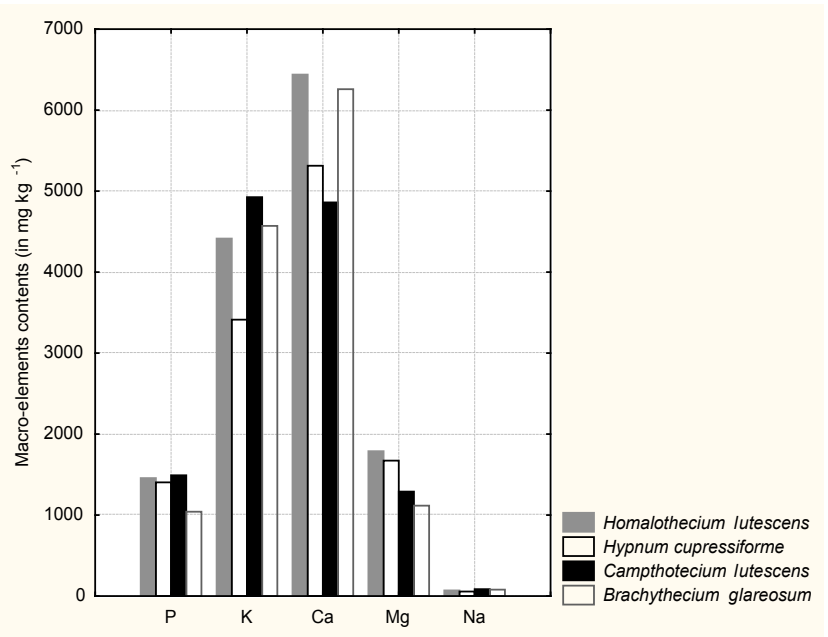

Figure 3: Variability assessment of quantity elements (P, K, Ca, Mg, $\mathrm{Na}$ ) between moss species; no significant variations were found.

of the pollution source. The median value for lead contents $\left(3.2 \mathrm{mg} \mathrm{kg}^{-1}\right)$ compared to the same value for the whole territory of the Republic of Macedonia ( $\left.4.6 \mathrm{mg} \mathrm{kg}^{-1}\right)$ shows no enrichments at all [14]. If close mine locations are isolated from the rest of the study area an enrichment of 10 times was obtained for 12 samples $\left(33.4 \mathrm{mg} \mathrm{kg}^{-1}\right)$. Fine dust from flotation tailings is distributed due to winds caring out, and deposited on moss. Almost $0.05 \%$ of these heavy metals are accumulated in the moss plant tissue, confirming how good adsorbers/absorpbers of heavy metals are. Significant skewed distributions were main problem in data processing. The rest of the potentially hazardous elements distributes in ranges for As $\left(0.03-10.5 \mathrm{mg} \mathrm{kg}^{-1}\right), \mathrm{Cd}\left(0.06-1.62 \mathrm{mg} \mathrm{kg}^{-1}\right), \mathrm{Hg}(0.01-$ $\left.0.04 \mathrm{mg} \mathrm{kg}^{-1}\right)$, Ni $\left(0.45-9.43 \mathrm{mg} \mathrm{kg}^{-1}\right)$. The lead-zinc deposits usually are characterized with $\mathrm{Mn}$ contents as well. Therefore, the Mn contents were ranged in $30.4-815 \mathrm{mg} \mathrm{kg}^{-1}$, wherefrom it can be considered geoenrichments in the study area.

Lead and zinc were distinguished as main anthropogenic introduced elements in the mine environment. The logarithmic values were used in the interpretation of the $\mathrm{Pb}$ and $\mathrm{Zn}$ distribution. Aerial distribution of dust particles is certainly in relation to the distance at which they can reach. Therefore, a functional dependence of the content versus distance from the emission source was established. Functional interdependence relation of elements contents across the distance from the pollution source was determined. Significant higher negative correlation ( $r$ $=-0.43$ and -0.54 , respectively for $\mathrm{Pb}$ and $\mathrm{Zn}$ ) was derived from the relation given in figure 2 , indicating that distancing from emission source, results in decrease of bio-accumulation of these heavy metals in moss (Table 4).

Interspecies comparison of bio-indicating ability of the collected four moss species was performed in order to determine whether there is a statistically significant difference in the accumulation of certain elements. The macro elements content does not show any significant variations in moss tissues as given in figure 3 . Phosphorus is accumulated in the ranges $\sim 0.1 \%$ as same as $\mathrm{Mg}$. Calcium contents ranges from $0.4-0.6 \%$ in all four moss species. Sodium is the mainly accumulated macro element in ranges of $55-85 \mathrm{mg} \mathrm{kg}^{-1}$.

Micro elements (Al, Mn, Fe, B, Ba, Cu, Sr, and $\mathrm{Zn}$ ) similar to macro elements contents do not significantly vary between the moss species based on their average values (Figure 4). However, if we consider that the higher content of certain micro elements are introduced in the mine environment, contents enrichment occurred. Such is the case with $\mathrm{Mn}$ and $\mathrm{Zn}$ contents where the maximum values of 815 and $179 \mathrm{mg} \mathrm{kg}^{-1}$, respectively, are obtained from Homalothecium lutescens moss tissue sample. Hypnum cupressiforme showed higher bioaccumulation ability for $\mathrm{Al}$ and $\mathrm{Ba}$ as micro elements and $\mathrm{Cr}, \mathrm{Ga}$ and $\mathrm{Li}$ as trace elements. Certain predominance of Homalothecium lutescens occurs in relation to the accumulation of potentially hazardous elements $\mathrm{As}, \mathrm{Cd}, \mathrm{Cr}$ and $\mathrm{Pb}$, but it should be considered that this is the dominant collected species in the study area (Figure 5). Campthotecium lutescens and Brachythecium glareosum are less dominant species but no deviation in average values for all analyzed elements were found. Considering this, no specific trend in the elements distribution pattern in mosses species were found (Figures 3-5). This evidence suggests that environmental factors influence element distribution between moss species.

By the application of multivariate statistics, three geogenic and one anthropogenic association were established on the basis of: a) visual inspection of similarities of spatial distribution of element patterns in moss samples; b) comparison of basic statistical parameters; c) the

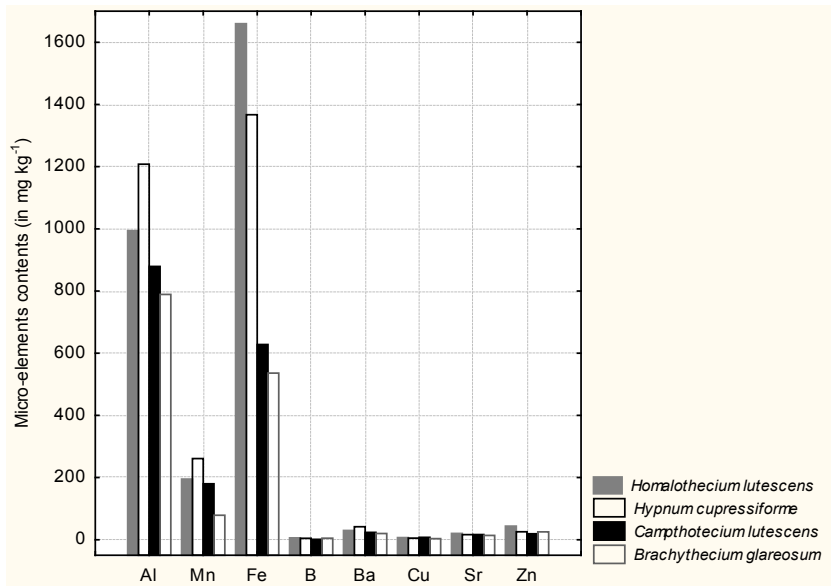

Figure 4: Variability assessment of micro essential elements (AI, Mn, Fe, B $\mathrm{Ba}, \mathrm{Cu}, \mathrm{Sr}, \mathrm{Zn}$ ) between moss species; significant variation were found only for Fe contents. 
Citation: Angelovska S, Stafilov T, Balabanova B, Sajn R, Baceva K (2014) Applicability of Atomic Emission and Atomic Absorption Spectrometry for Variability Assessment of Trace and Macro-Elements Content in Moss Species from Pb-Zn Mine Environment. Mod Chem appl 2: 123. doi:10.4172/2329-6798.1000123

Page 5 of 6

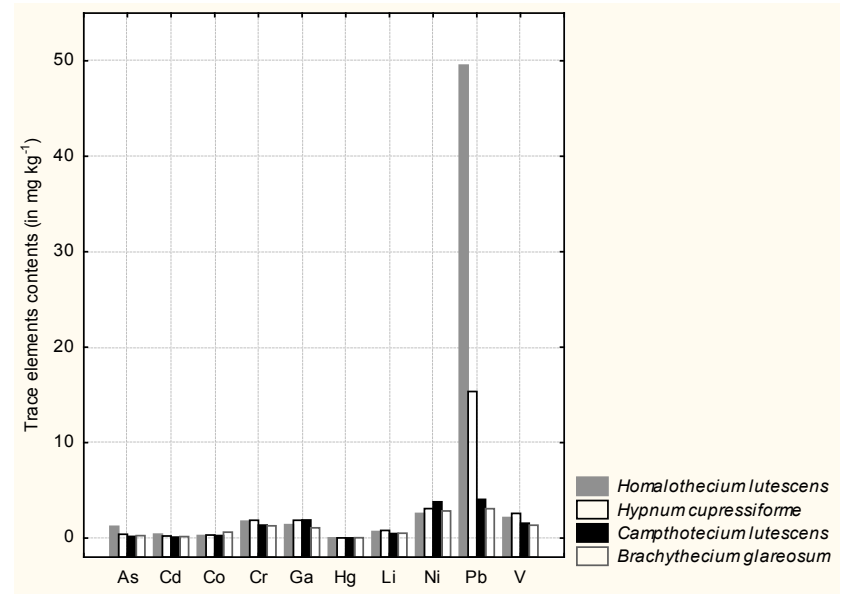

Figure 5: Variability assessment of trace elements (As, Cd, Co, Cr, Ga, $\mathrm{Hg}$ $\mathrm{Li}, \mathrm{Ni}, \mathrm{Pb}, \mathrm{V}$ ) between moss species. The element lead detected by ETAAS was present in the Toranica mine mosses to the highest amounts out of all trace elements.

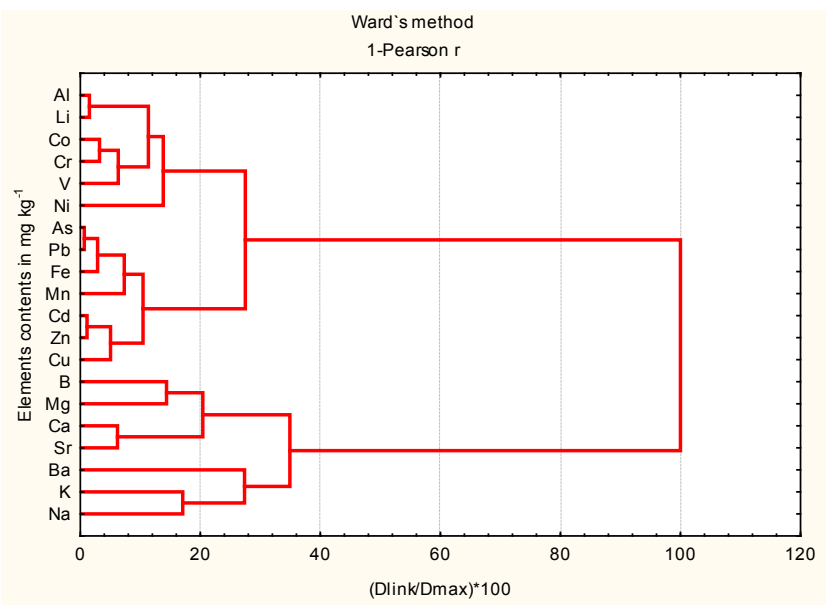

Figure 6: Cluster dendogram for elements contents, Pearson correlation coefficient was used to cluster together variable or samples with similar behavior. The dendrograms were performed using the linkage distance reported as Dlink/Dmax.

correlation coefficient matrices; d) the results of multivariate (cluster and Factor Analysis, FA) analyses (Figure 6 and Table 5). Pearson correlation coefficient was used to cluster together variable or samples with similar characteristics. The distribution of the normal variable in FA was reduced, excluding $\mathrm{Al}, \mathrm{Na}, \mathrm{Sr}, \mathrm{Mg}, \mathrm{Ga}, \mathrm{Ba}$ and $\mathrm{B}$, because of their very low factor loadings.

Four factors were identified, when applying FA that includes $87 \%$ of variability of the treated elements. Factor 1 (F1) is the strongest factor representing $40 \%$ of the total variability. This factor principally associates $\mathrm{As}, \mathrm{Cd}, \mathrm{Ca}, \mathrm{Cu}, \mathrm{Fe}, \mathrm{Mn}, \mathrm{Pb}$, and $\mathrm{Zn}$, which for the most of the elements are presumed to be of anthropogenic origin. Only the Ca distribution does not relay on anthropogenic introduction, but higher content as macro-element and mechanisms of adsorption as $\mathrm{Ca}^{2+}$ ion metal, consequented with stronger correlation with the others elements from F1. Factor 2 (F2) is the second strongest factor, with $23 \%$ of total variability. With this factor were associated elements Co, $\mathrm{Cr}, \mathrm{Li}$ and $\mathrm{V}$. The group also links elements that are probably naturally and anthropogenically distributed. Second geochemical association represents chemical elements that are probably naturally distributed. Factor 3 (F3) is the third strongest factor, with almost $12 \%$ of total variability. Significantly higher correlation of $\mathrm{Hg}-\mathrm{P}$ was estimated for F3, due to obtained factor loadings ( 0.90 and -0.92 , respectively). Therefore, the $\mathrm{Hg}$ accumulation in moss plant species probably is consequently dependent with phosphorus accumulation. The weakest expressive Factor 4 - F4, includes only $\mathrm{K}$, represents $8 \%$ of the total variability. However, clustering extends the elements distribution linkage to $\mathrm{K}$ with $\mathrm{Na}$ and $\mathrm{Ba}$ (Figure 3 ). The same effect was achieved for the F3 where $\mathrm{Ni}$ was linked with the geochemical association $\mathrm{Al}-\mathrm{Li}$ Co-Cr-V-Ni (Figure 6 and Table 5).

Clustering the 23 elements distributions to four synthetic variables (elements associations) was more reproductive vs. FA. The geochemical association Al-Li-Co-Cr-V confirms the dust dispersion in the investigated area, due to that element are mainly characteristic to soil particles. Moss species placed the particles with the physical absorption or adsorption from moss surface. The geochemical associations of $\mathrm{B}-\mathrm{Mg}-\mathrm{Ca}-\mathrm{Sr}$ and $\mathrm{Ba}-\mathrm{K}-\mathrm{Na}$ associate elements primarily affected by natural factors such as lithological background with no characteristic anthropogenic influence. Implementing clustering the elements $\mathrm{Hg}, \mathrm{Ga}$, $\mathrm{Ni}$ and $\mathrm{P}$ were excluded, consequently because of no similarity linkage.

Anthropogenic impact occurs at geochemical association distribution of As-Pb-Fe-Mn-Cd-Zn-Cu. Typical elements which are consequences of air transport from flotation tailings and are not influenced by lithological background. High values are found in the close mine environ along the Kriva Reka Canyon. This factor is connected with pollution by the lead and zinc flotation tailing dam dust dispersion. Association of $\mathrm{Fe}$ in this factor indicates anthropogenic influence, although all southeastern countries Serbia, Bulgaria, Turkey and Macedonia reported high median values for $\mathrm{Fe}$ indicating a natural source of this element [14]. Normal distribution of $\mathrm{Mn}$ in moss species ranges $30 \sim 200 \mathrm{mg} \mathrm{kg}^{-1}$, but in the present case, the maximal value was $815 \mathrm{mg} \mathrm{kg}^{-1}$, indicating a significant $\mathrm{Mn}$ anthropogenic introduction in the investigated area. Considering this, Mn occurring in higher contents is expected phenomena, due to the lead-zinc ore deposits containing significant amounts of $\mathrm{Mn}$.

Areal distribution maps were constructed in order to be determine

\begin{tabular}{|c|c|c|c|c|c|}
\hline Elements & F1 & F2 & F3 & F4 & Comm. \\
\hline $\mathrm{As}$ & 0.92 & 0.16 & 0.02 & 0.05 & 0.98 \\
\hline $\mathrm{Ca}$ & 0.76 & 0.01 & 0.34 & -0.03 & 0.85 \\
\hline $\mathrm{Cd}$ & 0.91 & 0.09 & 0.16 & -0.02 & 0.96 \\
\hline $\mathrm{Cu}$ & 0.85 & 0.06 & -0.27 & -0.15 & 0.84 \\
\hline $\mathrm{Fe}$ & 0.88 & 0.39 & 0.00 & 0.21 & 0.98 \\
\hline $\mathrm{Mn}$ & 0.77 & 0.21 & -0.13 & 0.26 & 0.87 \\
\hline $\mathrm{Pb}$ & 0.94 & 0.15 & 0.02 & 0.03 & 0.98 \\
\hline $\mathrm{Zn}$ & 0.97 & 0.09 & 0.07 & -0.01 & 0.99 \\
\hline $\mathrm{Co}$ & -0.23 & 0.80 & 0.21 & -0.40 & 0.89 \\
\hline $\mathrm{Cr}$ & 0.51 & 0.70 & -0.02 & 0.30 & 0.91 \\
\hline $\mathrm{Li}$ & 0.16 & 0.89 & 0.08 & 0.11 & 0.89 \\
\hline $\mathrm{V}$ & 0.28 & 0.82 & 0.03 & 0.20 & 0.89 \\
\hline $\mathrm{Hg}$ & 0.10 & 0.06 & 0.90 & 0.02 & 0.78 \\
\hline $\mathrm{P}$ & 0.01 & -0.08 & -0.92 & -0.10 & 0.77 \\
\hline $\mathrm{K}$ & -0.05 & -0.27 & -0.18 & -0.83 & 0.71 \\
\hline $\mathrm{Var}$. & 0.40 & 0.23 & 0.12 & 0.08 & 0.87 \\
\hline
\end{tabular}

Table 5: Factor loadings for elements contents in moss samples.

F1, F2, F3, F4 - Factor loadings values; Comm: Communality; Var: Specific variance. 
Citation: Angelovska S, Stafilov T, Balabanova B, Sajn R, Baceva K (2014) Applicability of Atomic Emission and Atomic Absorption Spectrometry for Variability Assessment of Trace and Macro-Elements Content in Moss Species from Pb-Zn Mine Environment. Mod Chem appl 2: 123. doi:10.4172/2329-6798.1000123

Page 6 of 6
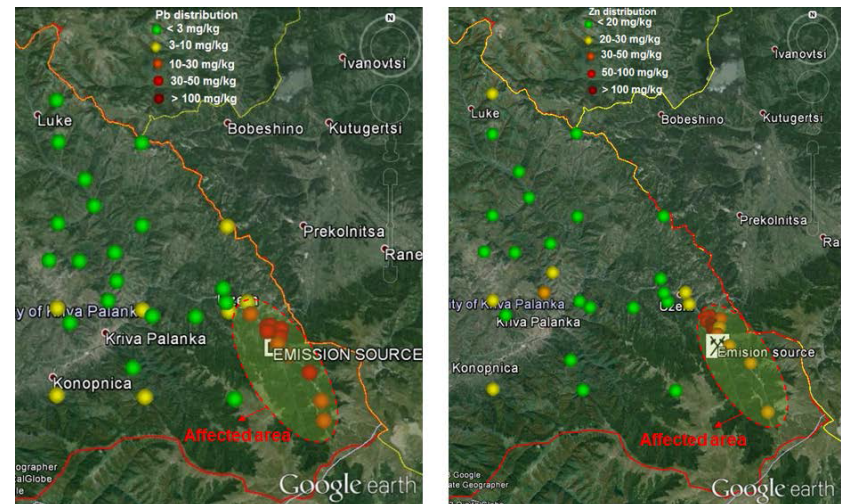

Figure 7: A real total contents distribution of main anthropogenic markers of $\mathrm{Pb}$ (left) and $\mathrm{Zn}$ (right) in "Toranica" lead-zinc mine environ. Distribution range for $\mathrm{Pb}$ is $0.4-420 \mathrm{mg} \mathrm{kg}^{-1}$ and for $\mathrm{Zn}$ is $6.7-180 \mathrm{mg} \mathrm{kg}^{-1}$, set in five sub contents.

the very close areas that are affected with hazardous contents of lead and zinc (contents $>100 \mathrm{mg} \mathrm{kg}^{-1}$ ), as presented in figure 7 . The topography of the region is characterized as mountainous with reduced dust air distribution. The effect of contamination caused by flotation tailings open dam is occurring along in north direction from the flotation dam. Long distance distribution from the pollution source does not occur.

\section{Conclusions}

The applicability of ICP-AES, ETAAS and CVAAS for determinations of twenty three elements contents in moss species is presented. The ICPAES technique was applied for determining the total contents of $\mathrm{Al}, \mathrm{B}$, $\mathrm{Ba} \mathrm{Ca}, \mathrm{Cr}, \mathrm{Cu}, \mathrm{Ga}, \mathrm{Fe}, \mathrm{K}, \mathrm{Li}, \mathrm{Mg}, \mathrm{Mn}, \mathrm{Na}, \mathrm{Ni}, \mathrm{P}, \mathrm{Pb}, \mathrm{Sr}, \mathrm{V}, \mathrm{Zn}$; the ETAAS for determination of As, Cd, Co; and CVAAS for determining the total content of mercury in moss samples. It was established that the applied instrumental techniques are useful in order to determine a wider range of concentrations for the analyzed elements. Metals biomonitoring with naturally growing mosses technique was used in dependence of four moss species (Homalothecium lutescens, Hypnum cupressiforme, Brachythecium glareosum and Campthotecium lutescens) in the $\mathrm{Pb}-\mathrm{Zn}$ mining area of "Toranica" mine, Republic of Macedonia. Results show that $\mathrm{Pb}$ and $\mathrm{Zn}$, occurring as main markers for anthropogenic impacts of the pollution source associated with $\mathrm{As}, \mathrm{Cd}, \mathrm{Cu}$, and $\mathrm{Mn}$, strongly correlated in moss samples. Highest bioaccumulation values are found immediately near the flotation tailing dam, decreasing rapidly with distance. Dispersion of fine dust from mining operations presents a serious environmental problem. Deposition patterns resulting from metal biomonitoring may help regional authorities to locate precipitation collectors for direct chemical analysis, in order to conduct further ecological and/or epidemiological surveys.

\section{References}

1. Longchurst JWS, Brebbia CA (2013) Air Pollution. WIT Press, Great Britain.

2. Athar M, Vohora S (1995) Heavy metals and environment. New Age International Publishers, New Delhi.

3. Acton QA (2013) Issues in environmental health and pollution. Scholatity Edition press, Atlanta, Georgia, USA.

4. Duruibe JO, Ogwuegbu MOC, Egwurugwu JN (2007) Heavy metal pollution and human biotoxic effects. International Journal of Physical Sciences 2: 112118.

5. Balabanova B, Stafilov T, Baceva K, Sajn R (2010) Biomonitoring of atmospheric pollution with heavy metals in the copper mine vicinity located near Radovis, Republic of Macedonia. J Environ Sci Health A Tox Hazard Subst Environ Eng 45: 1504-1518.
6. Balabanova B, Stafilov T, Sajn R, Baceva K (2013) Comparison of response of moss, lichens and attic dust to geology and atmospheric pollution from copper mine. International journal of Environmental Science and Technology 11: 517528.

7. Baceva K, Stafilov T, Sajn R, Tanaselia C (2012) Moss biomonitoring of air pollution with heavy metals in the vicinity of a ferronickel smelter plant. J Environ Sci Health A Tox Hazard Subst Environ Eng 47: 645-656.

8. Baceva K, Stafilov T, Sajn R, Tanaselia C (2013) Air dispersion of heavy metals in the vicinity of the As-Sb-Tl abounded mine and responsiveness of moss as a biomonitoring media in small-scale investigations. Environ Sci Pollut Res Int 20: 8763-8779.

9. Onianwa PC (2001) Monitoring atmospheric metal pollution: a review of the use of mosses as indicators. Environ Monit Assess 71: 13-50.

10. Markert BA, Breure AM, Zechmeister HG (2003) Definitions, strategies, and principles for bioindication/biomonitoring of the environment. Bioindicators \& Biomonitors. Principles, Concepts and Applications, Elsevier, Oxford, UK.

11. Fernandez JA, Aboal JA, Real C, Carballeira A(2007)A new moss biomonitoring method for detecting sources of small scale pollution. Atmospheric Environment 41: 2098-2110.

12. Vuckovic I, Spiric Z, Stafilov T, Kusan V (2013) Atmospheric deposition of cadmium in Croatia studied by using moss biomonitoring technique and ICP. AES. Geologica Macedonica 26: 11-19.

13. Spiric Z, Vuckovic I, Stafilov T, Kusan V, Frontasyeva M (2013) Air pollution study in Croatia using moss biomonitoring and ICP-AES and AAS analytical techniques. Arch Environ Contam Toxicol 65: 33-46.

14. Barandovski, L, Stafilov, T., Sajn, R, Frontasyeva, MV, Baceva, K (2013) Air pollution study in Macedonia by using moss biomonitoring technique, ICP-AES and AAS. Macedonian Journal of Chemistry and Chemical Engineering 32: 89107.

15. Serafimovski T, Dolenec T, Tasev G (2006) Actinolite-phengite-chlorite metasomatites from the Toranica $\mathrm{Pb}-\mathrm{Zn}$ ore deposit in Macedonia. RMZ Materials and Geoenvironment 53: 445-453.

16. Dobrovolskaya MG, Stankovski R (1997) Structural-textural relations and succession of ore deposition in the Toranica $\mathrm{Pb}-\mathrm{Zn}$ deposit (Macedonia) Geology of Ore Deposits C/C of Geologiia Rudnykh Mestorozhdenii 39: 79-92.

17. Lazarevski A (1993) Climate in Macedonia, Kultura, Skopje,(in Macedonian).

18. Harmens H (Editor) (2010) Monitoring of atmospheric deposition of heavy metals, nitrogen and POPs in Europe using bryophytes, Monitoring manual Centre for Ecology and Hydrology, Environment Centre Wales, Bangor, UK.

19. Serafimovski I, Karadjova I, Stafilov T, Cvetkovic J (2008) Determination of inorganic and methylmercury in fish by cold vapor atomic absorption spectrometry and inductively coupled plasma atomic emission spectrometry. Microchemical Journal 89: 42-47.

20. Steinnes E, Ruhling A, Lippo, H, Makinen A (1997) Reference materials fo large-scale metal deposition surveys. Accreditation and Quality Assurance 2: 243-249.

21. Filzmoser P, Garrett RG, Reimann C (2005) Multivariate outlier detection in exploration geochemistry. Computers \& Geosciences 31: 579-587.

22. Zibret G, Sajn R (2010) Hunting for geochemical associations of elements: factor analysis and self-organizing maps. Mathematical Geosciences 42: 681703. 